\title{
AN INVESTIGATION OF THE QUALITY OF DRINKING WATER FROM COMMERCIAL WATER BOREHOLES IN PARTS OF KANO MUNICIPALITY IN NORTHERN NIGERIA
}

\author{
Amatobi Damiana Ada ${ }^{1}$ \\ ${ }^{I}$ Department of Civil Engineering, Akanu Ibiam Federal Polytechnic Unwana, Afikpo, Ebonyi State, Nigeria
}

\begin{abstract}
The gross inadequacy of public municipal drinking water supply in Nigeria compels individuals to make alternative arrangements for their drinking water supplies. In Kano, many people have embraced the sinking of water boreholes to obtain drinking water for private or commercial use, or both. In most cases the water is used directly for drinking, cooking and personal hygiene without any treatment. This paper investigates the quality of drinking water supplied from commercial boreholes in a selected area of Kano in Northern Nigeria. Samples of water from six commercial water boreholes, spread across Bomkpai and Yankaba, Niger Street and Airport Road-all in Kano municipality-were analyzed for physico-chemical and bacteriological quality. Two boreholes from the Bomkpai area were found to contain lead and chromium in the excess of the World Health Organization (WHO) and the Nigerian Standard for Drinking Water Quality (NSDWQ) recommended limits. Samples from all the boreholes studied were above limits of WHO and NSDWQ standards in colonies of micro-organism and coliform organism. The paper concludes that the quality of drinking water from six investigated commercial water boreholes in Kano raises health concerns. It recommends proper government regulation of commercial water boreholes in Kano; enforcement of periodic water quality checks.; and subjecting all commercial water boreholes in the Bomkpai area of Kano to water quality analysis, especially to determine the levels of heavy metals, such as lead and Chromium.
\end{abstract}

Keywords: Borehole, Commercial, Drinking Water, Health, Regulation. $* * *$

\section{INTRODUCTION}

Water is a basic necessity of life, and as such a "right to water" may be regarded as a "right to life." In line with this thought, the former Secretary General of United Nations, Koffi Annan (2001: Bichi and Amatobi, 2013) is right to describe water as "a basic human right." Section 33 of Nigerian constitution recognized "“right to life" as a fundamental human right (FRN, 1999). Theoretically, it presupposes that in pursuance of human rights in Nigeria the provision of safe and adequate drinking water should be a top priority at all levels of government. However, this is not practically the case, because majority of Nigerian citizens, in both the rural and urban areas, are still being denied access to safe and adequate drinking water. According to reports, only about $15 \%$ and $50 \%$ of rural and urban dwellers, respectively, have adequate and reliable access to drinking water (Amatobi 2016: Muta'aHellandendu, 2015, FRN, 2000) This is in spite of the fact that the country is endowed with abundant water resources. According to Muta'a Hellandendu (2012) Nigeria is yet to "successfully harness these resources to ensure a sustainable and equitable access to safe, adequate, improved and affordable water supply and sanitation to its population" The Water Aids Nigeria (2016) corroborated this statement by asserting that over 63 million people in Nigeria lack access to safe drinking water because "water services cannot be delivered quickly enough to cope with the rapidly growing population".
The human need for water has no substitute, and in times of water scarcity people usually look for water for domestic use from any available source without due regard to water quality. In Nigeria, due to the slow pace, or near absence of government intervention at providing adequate and safe drinking water for citizens, people seek self-help alternatives which include:

i. fetching of water from surface sources such as rivers, streams, springs and lake;

ii. harvesting rainwater from roof tops;

iii. abstracting water from water boreholes or wells; and

iv. Buying water from vendors and hawkers whose sources may be any of the three above.

These sources of self-help water supply are often associated with health risks, because the water quality cannot be guaranteed, since more often than not a proper water treatment is not carried out.

Commercial water borehole is becoming the most popular source of drinking water for both the urban and the rural dwellers in Kano. A borehole is a vertical hole bored into the ground down into the 'water table' (i.e. into the water saturated zone of the underground) so that groundwater can be abstracted through the hole, usually by means of a pump. A professionally constructed and well maintained borehole has some advantages which include relatively low cost of 
construction and maintenance; nearness of source to point of use; less susceptibility to pollution from surface activities (sewage, flood, solid waste, etc) ; and less need for treatment. According to Linsley et al (1992), an important advantage of groundwater as a source of domestic supply is its comparative freedom from bacterial and chemical pollution. Water that percolates through fine-grained materials is usually cleared of bacterial pollution within the depth of 30m. Agunwamba (2008) stated that a properly designed and constructed borehole can be put to use for over 30 years. According to him, "a successful pumping borehole requires an experienced hydro-geologist to locate the site, a competent drilling contractor using modern techniques and materials, and correct selection of a pump." On the other hand, when a borehole is improperly designed, constructed, or maintained, polluted surface water can easily intrude into the hole, and also pathogens introduced during construction stages can remain inside (Linsley et al, 1992). Duru (2014) posits that in the absence of planning and adoption of profession procedures, the proliferation of boreholes can lead to widespread of pollution and contamination. Okereke (2010) asserted that Nigerians do not usually purify water from boreholes before consumption. He warned that even though the borehole water is a groundwater, it can be "easily contaminated by leaky contaminants, heavy metals and micro organisms". The former Lagos State Governor, Raji Fashola, now a Federal Minister, was quoted to have suggested that boreholes in Nigeria should be shut down because "they have long term environmental impact and environmental damage" ( Olufowobi,2012 ).

Kano is one of the states in Nigeria where commercial water boreholes flourish as source of drinking water. It is nowadays a common practice in Kano for house owners to sink boreholes within their compound and then make water sales points near the compound, usually in front of the fence. Members from the neighbourhood, including water vendors (or hawkers) buy the water, usually in jeri-cans. Often, what matters is the availability of water. Except when there are issues of obvious objectionable colour or odour; quality is usually taken for granted. It is, however, important that the quality of water from every borehole, especially those used for commercial purposes is known. This is because dangers are imposed on public health whenever a drinking water source becomes polluted or contaminated. These dangers include the outbreak of water-borne diseases such as diarrhoea, cholera and typhoid fever, and complications arising from intake of water containing toxic levels of chemicals like lead, chromium and arsenic, including problems like mental retardation in children, organ failure, cancer, etc. This paper investigates the quality of drinking water supplied from commercial water boreholes in selected areas of Kano in Northern Nigeria.

\section{MATERIALS AND METHODS}

\subsection{The Study Area}

The study area covers Bomkpai, Yankaba, Niger Street and Airport Road; .all in Kano municipality. Bomkpai is largely an industrial area with manufacturing activities in textile, food, plastics, drugs, chemicals, etc, while Yankaba is a residential community and has a popular fresh fruits and vegetables market, called "Yankaba Market." Niger Street and Airport Road are commercial/residential areas close to one of the biggest markets in Kano called "Abububakar Rimi Market."

\subsection{Sample Collection}

Six commercial boreholes that enjoy very high patronage were identified and were investigated in the study area. The boreholes were designated as A, B, C, D, E and F. Boreholes A and B are located at Niger street and airport road respectively, $\mathrm{C}$ and $\mathrm{D}$ are located at Yankaba, at Adua and at Badawa axis, respectively; and $\mathrm{E}$ and $\mathrm{F}$ are at Bomkpai Club Road and Bomkpai Independent Road respectively.

The water samples were collected from the boreholes using sterilized bottles having stoppers. Precautionary measures were taken to ensure that the samples represented the source of collection. Thus clinical hand gloves were worn to avoid contact. Each water source was allowed to flush out before sampling; and each sample bottle was rinsed three times with the source water before being filled with the water sample. The sample bottles were labelled to show the source, date and time of collection. Each sample was transferred to the laboratory soon after collection. Bacteriological analyses were done within 48 hours of water sample collection while physco-chemical analyses were completed within 7 days of collection.

\subsection{Laboratory Tests}

The physico-chemical tests carried out include $\mathrm{pH}$, total hardness, permanent hardness, temporary hardness, colour, chloride, chloride and heavy metals. The heavy metals were zinc, chromium, lead, nickel, iron, manganese, magnesium and copper.

The bacteriological analyses were targeted at detection of colonies of micro-organisms, coliform organisms, and e-coli examination.

The laboratory tests and analysis were based on procedures detailed in Bichi and Amatobi (2013) 


\section{RESULTS AND DISCUSSION}

Table 3.1 Summary of physico-chemical parameters of water from commercial bore points in Kano with WHO and NSDQ limits

\begin{tabular}{|c|c|c|c|c|c|c|c|c|c|c|}
\hline Parameter & A & $B$ & C & D & E & $\mathrm{F}$ & mean & std deeviation & WHO (2004)limits & NSDWQ(2007) limits \\
\hline $\mathrm{ph}$ & 7.97 & 7.8 & 7.76 & 8.11 & 8.17 & 8.48 & 8 & & $6.5-8.4$ & $6.5-8.5$ \\
\hline Permanaent hardness & 207 & 130 & 68 & 105 & 145 & 120 & 129 & 46 & Ns & NS \\
\hline Temporary hardness & 130 & 90 & 51 & 89 & 110 & 98 & 95 & 26 & Ns & NS \\
\hline Total hardness & 337 & 220 & 119 & 194 & 255 & 218 & 224 & 72 & 500 & 150 \\
\hline colour (TCU) & 6 & 6 & 4 & 4 & 5 & 5 & 5.00 & 0.89 & 15 & 15 \\
\hline chloride & 1.8 & 1.7 & 1.2 & 1.6 & 1.5 & 1.7 & 1.58 & 0.21 & 250 & 250 \\
\hline Mangnesium & 0.42 & 0.37 & 0.6 & 0.23 & 0.23 & 0.45 & 0.38 & 0.14 & 150 & 0.2 \\
\hline Iron & 0.13 & 0.05 & 0.1 & 0.1 & 0.08 & 0.15 & 0.10 & 0.04 & 0.3 & 0.3 \\
\hline Manganese & 0.02 & 0.09 & 0.19 & 0.09 & 0.28 & 0.28 & 0.16 & 0.11 & 0.1 & 0.2 \\
\hline Nikel & 0.04 & 0.03 & 0.14 & 0.02 & 0.21 & 0.34 & 0.13 & 0.13 & 0.02 & 0.02 \\
\hline Zinc & 0.27 & 0.25 & 0.2 & 0.21 & 0.12 & 0.1 & 0.19 & 0.07 & 3 & 3 \\
\hline Lead & 0.02 & 0.06 & 0.01 & 0.05 & 0.14 & 0.12 & 0.07 & 0.05 & 0.01 & 0.01 \\
\hline Cromium & 0.04 & 0.03 & 0.06 & 0.05 & 0.59 & 0.3 & 0.18 & 0.23 & 0.05 & 0.05 \\
\hline copper & 0.2 & 0.05 & 0.05 & 0.1 & 0.14 & 0.1 & 0.11 & 0.06 & 2 & 1 \\
\hline
\end{tabular}

Source: field studies.

Table 3.1 shows a summary of the results of physicochemical analyses of water samples from commercial borehole points in Kano. The mean values of physicchemical parameters in most of the samples fall within the WHO and NSDWQ permissible limits. The exceptions include Total hardness which is within the limit of WHO but below the limit of NSDWQ and a few metals such as Nickel, Chromium, Nickel and Lead which were above both the WHO and NSDWQ limits. It is important to note that the samples that contained these metals in the excess of the limits were mostly from samples E and F which are in the industrial area of Bomkpai. According to ASTM (2004) nickel is relatively non-toxic to humans. Chromium may enter water as a result of industrial activities since chromium salts are used in industrial processes like metal finishing, electroplating, anodising, manufacture of paints and dies, etc. Excessive levels of chromium can cause gastro-intestinal disorders, convulsions, shock or death (Janus 1990). According to ALPA (1985), lead is usually found in traces in natural water but elevated levels can occur in water as a result of industrial, mine and smelter discharges, as well as from dissolution of lead plumbing materials. Lead can be a serious cumulative body poison (ASTM, 2004) and excessive lead in drinking water can cause delays in physical or mental development of infants and children. In adults lead can cause kidney problems and high blood pressure (USEPA, 2006)

Table 3.2: Summary of bacteriological parameters of commercial bore holes from sampled sites in Kano with WHO and NSDWQ

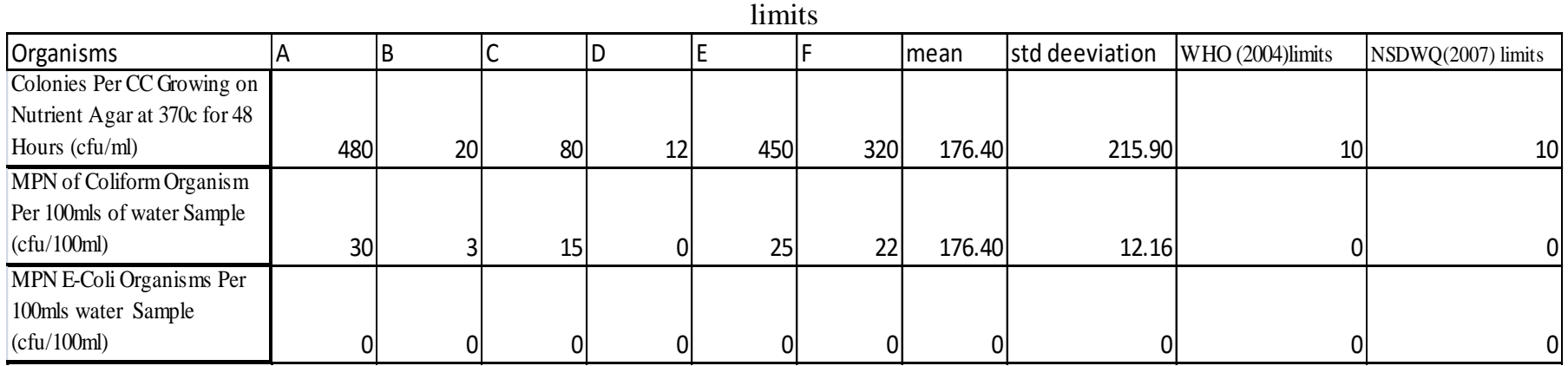

\section{Source: field studies}

Table 3.2 is a summary of bacteriological parameters from commercial borehole points in Kano. Almost all the samples were above the WHO and NSDWQ recommended limits in colonies of micro-organisms and the coliform organism. The presence of coliform organism can be a great health risk. This is because coliform organism in groundwater indicates that sewage or surface contaminants are entering the water source. In other words, when water tests confirm the presence of coliform organism there is an indication that other harmful bacteria might be present in the water. The result can be a reflection of the poor hygiene at the borehole sites. In all the sites sampled the well heads and water dispensing points were neither protected nor tidy, such that there was free access to all people, even animals. Some operators/ water sellers were also wearing dirty clothes. The operators/water sellers revealed to the researcher that they were neither trained on health/safety nor subjected to any medical examination before and during their employment in the commercial boreholes. No E-coli was detected in any of the samples, and that implies there was no recent faecal contamination during the study. 


\section{CONCLUSION AND RECOMMENDATIONS}

The quality of drinking water from six investigated commercial boreholes in Kano raises some health concerns. Lead and chromium were slightly above permissible limits at the Bomkpai sites. Most of the commercial boreholes studied were vulnerable to bacteriological contamination. The general poor hygienic conditions of the borehole sites, together with the lack of health/safety training and periodic medical examination of the commercial borehole equipment operators, constitute health hazard in Kano. It is difficult to confirm whether periodic quality checks are being carried out at the borehole sites by any body or agency since no evidence, including past records, of such checks was found during the study.

The following are the recommendations:

1. There is a need for State government to regulate the commercial water boreholes in Kano.

2. Periodic water quality checks, at least biannually, should be made compulsory for commercial drinking water suppliers.

3. All commercial borehole operators should be trained in the maintenance of proper hygiene and the protection of the borehole area in order to eliminate contamination from the surface.

4. Public health authorities in Kano should ensure that all personnel operating commercial drinking water equipment undergo compulsory periodic medical examination.

5. All commercial water boreholes in the Bomkpai area of Kano should be subjected to water quality analyses, especially to determine the toxic levels of heavy metals such as lead and Chromium.

\section{REFERENCES}

[1]. Amatobi, D. A. (2016). Effective water resources management as stimulus for national development: challenges and the way forward. Paper presented at the Technical Session, School of Engineering Technology (SET), 2016 Engineering and Technology Conference and Exhibition Akanu Ibiam Federal Polytechnic Unwana, Afikpo, Ebonyi State, Nigeria.

[2]. Anan, K. (2001): Message of UN Secretary-General Kofi Annan on World Water Day. Available at: http://www.worldwaterday.org/wwday/2001/index.html . [Assessed 20 July 2007]

[3]. APHA (1985): Standard methods for examination of water and wastewater; 16th edition. New York. American Public Health Association Inc.

[4]. ASTM (2004): Annual book of ASTM standards, water and environmental technology; New York: American Society for Testing and Materials, 11(01).

[5]. Bichi,M.H. and Amatobi, D. A.(2013) Assessment of the quality of water supplied by water vendors to households in Sabon-gari area of Kano, northern Nigeria. The International Journal of Engineering and sCience (IJES), 2(7):09-17.

[6]. Duru, P.N. (2014). Implications of borehole water as a substitute for urban water supply: The case of Egbeada
Federal Housing Estate Owerri, Imo State. International Journal for Innovation Education and Research,2(09) FRN (1999). Constitution of Federal Republic of Nigeria, 1999 [7]. Joseph Muta'aHellandendu(2012 Health implications of water scarcity in Nigeria. European Scientific Journal August edition vol. 8, No.18 ISSN: 1857 - 7881

[8]. Linsley, K.R;Franzini,B.J;FREYBERG,L.D. and Tchobanoglous, G. (1992). Water resources engineering. New York: McFraw-Hill,Inc.

[9]. Nnenna, D. P.(2014). Implications of borehole water as a substitute for uUrban water supply: the case of Egbeada Federal Housing Estate Owerri, Imo State. International Journal for Innovation Education and Research Vol.2-09,

[10]. Okereke, B.(2010).Nigerians' forced romance with boreholes and their waters: associated hazards starting from Orlu District in Imo State. Available at: http://www.nigeriavillagesquare.com/articles/benedictokereke/nigerians-forced-romance-with-boreholes-andtheir-waters-associated-hazards-starting-from.html [Assessed 08July 2016]

[11]. Olufowobi, S.(2012). Fashola raises the alarm on dangers of boreholes. available at : http://www.punchng.com/i-punch/ [Assessed May 18, 2016).

[12]. Punmia, B.C; Jain, Ashork and Jain, Arun (1995). Water supply engineering.New Delhi: laxmi Publications(P) Ltd.

[13]. WaterAid Nigeria ( 2016 ) What we do - The crisis Water. Avialable at: http://www.wateraid.org/ng/ [Assessed, 13 July 2016]. 